\title{
MENGUKUR KORELASI ANTARA TINGKAT KEMAPANAN TATA KELOLA TEKNOLOGI INFORMASI DENGAN PRODUKTIVITAS PERUSAHAAN
}

\author{
Annas Vijaya dan Budi Yuwono \\ Magister Teknologi Informasi, Fakultas Ilmu Komputer, Universitas Indonesia, Kampus Universitas \\ Indonesia (UI) Salemba, Jl. Salemba Raya nomor 4, Jakarta, 10430, Indonesia \\ E-mail: annas.vijaya @gmail.com
}

\begin{abstract}
Abstrak
Banyak literatur yang memaparkan manfaat penyelarasan antara Strategi Sistem Informasi/Teknologi Informasi (SI/TI) dengan strategi bisnis bagi keberhasilan organisasi. Penelitian ini dilakukan untuk melihat korelasi antara tingkat kemapanan suatu perusahaan dalam menyelaraskan strategi SI/TI dengan strategi bisnisnya dan produktivitas perusahaan tersebut. Penelitian ini dilakukan melalui studi kasus tunggal pada perusahaan perdagangan barang dan jasa teknologi informasi. Model yang digunakan dalam menilai tingkat kemapanan penyelarasan strategi SI/TI terhadap strategi bisnis adalah model tingkat kemapanan menurut kerangka kerja Control Objective for Information and Related Technology (COBIT). Ukuran produktivitas yang digunakan dalam penelitian ini adalah Total Factor Productivity (TFP). Melalui pengujian statistik non-parametrik dengan koefisien korelasi peringkat Spearman, tidak ditemukan korelasi positif antara tingkat kemapanan perusahaan dalam menyelaraskan strategi SI/TI dengan strategi bisnisnya dan produktivitas perusahaan. Sebagai kesimpulannya, dampak tingkat kemapanan penyelarasan strategi SI/TI melalui tata kelola TI terhadap produktivitas suatu organisasi tidak selalu dapat diukur dengan membandingkan keduanya dalam periode tahun yang sama.
\end{abstract}

Kata Kunci: tata kelola teknologi informasi, tingkat kemapanan, produktivitas bisnis

\begin{abstract}
Much of the literature describing the benefits of alignment between Strategy Information Systems/Information Technology (IS/IT) with business strategy for the success of the organization. The study was conducted to see the correlation between the level of reliability of a company's strategy in aligning IS/IT with business strategy and company productivity. The research was conducted through a single case study on trade in goods and services enterprise information technology. The model used in assessing the reliability of the alignment of strategy IS/IT to business strategy is a model framework for the establishment by the Control Objective for Information and Related Technology (COBIT). Productivity measures used in this study is Total Factor Productivity (TFP). Through the non-parametric statistical tests with Spearman rank correlation coefficient, was not found a positive correlation between the level of maturity in aligning corporate strategy IS/IT with business strategy and corporate productivity. In conclusion, the impact of strategic alignment maturity level of IS/IT through IT governance on the productivity of an organization can not always be measured by comparing the two in the same period.
\end{abstract}

Keywords: business productivity, governance of information technology, the maturity

\section{Pendahuluan}

Berbagai teori mengenai keselarasan antara strategi Sistem Informasi dan Teknologi Informasi (SI/TI) dengan strategi bisnis dapat ditemukan di beberapa literatur. Keselarasan strategis melalui harmonisasi SI/TI dengan bisnis dipandang sebagai salah satu kunci keberhasilan bisnis [1]. Akan tetapi, belum ada klaim yang menyatakan secara definitif bahwa peningkatan dalam kemampuan untuk melakukan penyelarasan tersebut dapat meningkatkan kinerja bisnis, misalnya produktivitas, perusahaan.
Salah satu model yang sering digunakan untuk mengukur tingkat kemapanan (maturity) dalam menyelaraskan strategi SI/TI dengan strategi bisnis adalah model tingkat kemapanan (maturity model) menurut Control Objective for Information and Related Technology (COBIT) versi 4.1 dari Information Technology Governance Institute (ITGI) [2]. COBIT 4.1 adalah suatu kerangka kerja yang merumuskan kontrol-kontrol yang banyak digunakan di organisasi-organisasi yang berhasil (best practice) dalam proses-proses pengelolaan SI/TI-nya. Kontrol-kontrol tersebut diterapkan untuk memastikan bahwa tujuan- 
tujuan pengelolaan dan pemanfaatan TI organisasi dapat tercapai. COBIT 4.1 juga menyediakan acuan untuk mengukur tingkat kemapanan penerapan kontrol-kontrol dalam berbagai proses pengelolaan SI/TI yang relevan bagi suatu organisasi. Semakin mapan penerapan kontrolkontrol tersebut berarti semakin terarah pengelolaan SI/TI untuk mendukung pencapaian tujuan bisnis perusahaan, dengan kata lain, akan semakin selaras strategi SI/TI dengan strategi bisnis organisasi.

Objek studi kasus pada penelitian ini adalah sebuah perusahaan terbuka, untuk memudahkan penulisan disebut sebagai PT ABC, yang bergerak di bidang perdagangan barang dan jasa teknologi informasi. PT ABC memiliki visi menjadi penyedia solusi bisnis berbasis teknologi informasi dan komunikasi terbaik di Indonesia. Pada akhir tahun 2007, PT ABC telah memiliki 22 cabang di seluruh Indonesia [3]. PT ABC telah memanfaatkan SI/TI sebagai penunjang dalam melakukan kegiatan bisnisnya. Untuk dapat mengetahui pengaruh tingkat kemapanan penyelarasan antara strategi SI/TI dengan strategi bisnis terhadap produktivitas perusahaan, PT ABC perlu meninjau tingkat kemapanan penyelarasan tersebut secara periodik. Dalam penelitian ini, diperoleh data yang dibutuhkan untuk tahun 2005, 2006, dan 2007. Penelitian ini ditujukan untuk menjawab pertanyaan: "Apakah tingkat kemapanan penyelarasan antara strategi SI/TI dengan strategi bisnis berpengaruh terhadap produktivitas PT ABC?"

Penelitian yang dilakukan Nash [4] mengukur pengaruh tingkat kemapanan keselarasan antara SI/TI dengan bisnis terhadap produktivitas dan profitabilitas organisasi. Pengukuran tingkat kemapanan dilakukan dengan menggunakan model kemapanan Luftman [5] yaitu Strategic Alignment Maturity Model (SAMA). Pengukuran produktivitas yang dilakukan oleh Nash menggunakan rumusan Total Factor Productivity (TFP), sedangkan untuk mengukur profitabilitas digunakan tiga paramenter yaitu tingkat penjualan, enterprisevalue-to-sales, dan net profit margin perusahaan. Dari studi literatur, diketahui bahwa dalam pengukuran produktivitas, metode yang lazim digunakan adalah menggunakan semua faktor produksi atau Produktivitas Faktor Total [6].

Penelitian yang dilakukan terhadap sembilan perusahaan farmasi ini bertujuan untuk mengetahui pengaruh tingkat kemapanan keselarasan strategis antara SI/TI dengan bisnis terhadap produktivitas dan profitabilitas perusahaan. Hasil dari penelitian tersebut adalah perusahaan yang memiliki profitabilitas dan produktivitas lebih tinggi adalah perusahaan yang memiliki tingkat kemapanan keselarasan strategis yang lebih tinggi serta Berdasarkan analisa korelasi antara peringkat SAMA dengan tingkat penjualan, ditemukan bahwa organisasi yang memiliki komunikasi antara pihak SI/TI dengan pihak bisnis yang buruk adalah organisasi yang memiliki peringkat produktivitas dan profitabilitas yang rendah. Selain itu, dari penelitian tersebut diketahui besarnya tingkat kesenjangan keselarasan strategis antara SI/TI dan bisnis berkorelasi positif terhadap besar kecilnya ukuran perusahaan. Ditunjukkan bahwa semakin besar perusahaan, semakin besar pula tingkat kesulitannya dalam melakukan komunikasi SI/TI dengan bisnis secara efektif.

COBIT adalah kerangka kerja yang telah diterima secara global sebagai basis dalam tata kelola TI (Information Technology Governance) yang menyediakan tools dan best practice untuk mengontrol berbagai proses dan aktivitas pengelolaan TI [7].

COBIT menyediakan model kemapanan penerapan kontrol-kontrol pada 34 proses pengelolaan SI/TI organisasi. Pendekatan yang digunakan oleh model kemapanan COBIT ini mengacu pada konsep model kemapanan kapabilitas atau Capability Maturity Model (CMM) dari Software Engineering Institute (SEI). Tingkat kemapanan suatu proses pada model tersebut memiliki nilai dari 0 (non-existent), 1 (ad-hoc), 2 (repeatable), 3 (defined), 4 (managed), hingga 5 (optimized). Suatu organisasi belum tentu harus menerapkan seluruh prosesproses pengelolaan TI menurut COBIT, melainkan hanya proses-proses yang mendukung tujuantujuan pengelolaan TI atau IT goals, yang pada gilirannya mendukung tujuan-tujuan pemanfaatan TI atau business goals organisasi tersebut. COBIT menyediakan pemetaan dari business goals, ke IT goals, sampai ke proses-proses pengelolaan TI.

\section{Metodologi}

Metode yang lazim digunakan dalam pengukuran produktivitas adalah menggunakan semua faktor produksi atau produktivitas faktor total (total factor productivity) [6]. Metode ini juga melibatkan unsur lain yang tercakup dalam pendapatan organisasi dan nilai aset yang dimiliki oleh organisasi tersebut. Perhitungan TFP yang digunakan dalam penelitian ini mengacu pada rumusan yang digunakan oleh Nash [4], yang melakukan pengukuran pengaruh keselarasan strategis antara SI/TI dengan bisnis terhadap produktivitas organisasi.

Persamaan TFP tersebut didefinisikan pada persmaan 1 berikut: 


$$
\mathrm{TFP}=\Delta \mathrm{RE}-(\Delta \mathrm{AE} \times \mathrm{K})
$$

di mana

$\triangle \mathrm{RE}$ : Persentase perubahan pada jumlah pendapatan organisasi per karyawan (the percentage change in revenue amount per employee)

$\triangle \mathrm{AE}$ : Persentase perubahan pada nilai aset organisasi per karyawan (the percentage change in assets per employee)

$\mathrm{K}$ : Konstanta yang merepresentasikan pengaruh dari investasi TI pada produktivitas

Nilai yang digunakan untuk $\mathrm{K}$ adalah 0.19 berbasis data dari APO Productivity Databook 2010, yang diterbitkan oleh Asian Productivity Organization [8]. Meskipun demikian, dikarenakan penelitian ini merupakan studi kasus tunggal yang hanya membutuhkan tren TFP saja dan bukan nilai detailnya, maka nilai konstanta ini tidak memiliki pengaruh besar terhadap pengujian yang dilakukan, dengan syarat bahwa nilai yang sama dengan batas antara 0 sampai 1 tetap digunakan secara konsisten pada setiap perhitungan TFP yang dilakukan.

Metodologi yang digunakan dalam penelitian ini bersifat kualitatif dengan desain studi kasus tunggal dan pengujian kualitas menggunakan validitas internal [9].

Langkah pertama adalah identifikasi Critical Success Factors (CSF) perusahaan pada rentang data penelitian (2005-2007) berdasarkan strategi bisnis perusahaan. Langkah selanjutnya adalah penentuan proses-proses pengelolaan TI menurut COBIT yang relevan dengan strategi bisnis perusahaan, yang diperoleh melalui pemetaan CSF perusahaan ke tujuan-tujuan pemanfaatan TI, dikenal sebagai business goals, menurut COBIT. Hasil dari pemetaan ini kemudian dilanjutkan dengan identifikasi tujuan-tujuan pengelolaan TI, dikenal sebagai IT goals, menurut COBIT. Identifikasi dilakukan dengan mengacu pada pemetaan antara business goals dengan IT goals yang mendukung pencapaiannya, yang terdapat pada COBIT [2]. Dari IT goals yang relevan dengan strategi bisnis perusahaan, dapat diidentifikasi proses-proses pengelolaan TI yang relevan berdasarkan pemetaan IT goals ke prosesproses menurut COBIT.

Langkah selanjutnya adalah mengukur tingkat kemapanan proses-proses pengelolaan TI yang telah diidentifikasi sebelumnya berdasarkan kriteria kemapanan penerapan kontrol-kontrol yang didefinisikan dalam COBIT. Akan tetapi, karena rentang waktu penelitian terjadi di masa lalu, diperlukan data tingkat kemapanan masa lalu yang kebetulan dimiliki oleh perusahaan, walaupun tidak mengacu pada struktur proses pengelolaan TI menurut COBIT. PT ABC telah melakukan penilaian tingkat kemapanan pengelolaan layanan TI atau Information Technology Service Management (ITSM) yang berbasis pada kerangka kerja Information Technology Infrastructure Library (ITIL) dari Office of Governance Commerce di Inggris. Dari data yang ada, tingkat kemapanan proses-proses COBIT yang terpilih tidak dapat diperoleh secara langsung, melainkan harus diambil dari topiktopik pada ITIL yang berkontribusi pada prosesproses COBIT yang akan diukur. Pemetaan antara proses-proses COBIT 4.1 dengan ITIL versi 3 telah diterbitkan oleh ITGI pada tahun 2008 [7].

Langkah terakhir dari penelitian ini adalah melakukan analisa korelasi antara tingkat kemapanan penyelarasan strategi bisnis SI/TI dengan strategi bisnis dan produktivitas perusahaan. Tingkat produktivitas perusahaan didapatkan melalui perhitungan indikator produktivitas faktor total perusahaan. Pengujian statistik non-parametrik dengan koefisien korelasi peringkat Spearman [10] digunakan dalam analisa ini untuk menunjukan hubungan antara tingkat penyelarasan strategi SI/TI dengan strategi bisnis dan produktivitas perusahaan.

Hipotesis penelitian ini adalah:

H0: Tingkat kemapanan penyelarasan strategi SI/TI terhadap strategi bisnis tidak berpengaruh positif terhadap TFP organisasi.

H1: Tingkat kemapanan penyelarasan strategi SI/TI terhadap strategi bisnis berpengaruh positif terhadap TFP organisasi.

\section{Hasil dan Pembahasan}

Untuk mendapatkan proses-proses pengelolaan TI yang akan diukur tingkat kemapanannya, langkah-langkahnya adalah mengidentifikasi CSF dari strategi bisnis perusahaan, mengidentifikasi business goals menurut COBIT yang relevan dengan CSF tersebut, mengidentifikasi IT goals menurut COBIT yang mendukung business goals tersebut, dan mengidentifikasi proses-proses pengelolaan yang mendukung IT goals tersebut. Hal ini dilakukan untuk masing-masing periode tahun dari rentang waktu penelitian, yaitu 2005, 2006, dan 2007. Karena keterbatasan ruang, hanya periode tahun 2005 yang dibahas untuk memberikan gambaran bagaimana analisa ini dilakukan.

Tabel I menjabarkan strategi bisnis PT ABC pada tahun 2005 beserta CSF yang telah dinyatakan dalam dokumen rencana strategis PT ABC.

Dengan menggunakan tabel pemetaan business goals ke IT goals COBIT, CSF strategi 
bisnis tahun 2005 dapat digunakan untuk mengidentifikasi IT goals yang relevan bagi pelaksanaan strategi bisnis tahun 2005, sebagaimana terlihat pada tabel II.

TABEL I

STRATEGI BISNIS PT ABC TAHUN 2005 DAN CRITICAL SUCCESS FACTORS UNTUK TIAP KOMPONEN STRATEGI

05S1 Strategi bisnis 1:

Peningkatan kompetensi solusi berbasis TI.

05S1- Pengembangan pada segmen Services

CSF1 Business melalui optimalisasi semua

portofolio produk yang masuk kelompok Services Business.

05S1- Penguatan manajemen berkualitas

CSF2 dengan memperpanjang sertifikasi ISO9001.

05S1- Pembenahan data.

CSF3

05S2 Strategi bisnis 2:

Memperkokoh daya saing dan meningkatkan kontribusi bagi perusahaan.

05S2- Peningkatan efektifitas jaringan

CSF1 pemasaran melalui kebijakan-kebijakan yang berorientasi penguasaan pasar secara baik.

05S2- produktivitas karyawan melalui

CSF2 program-program motivasi dan peningkatan pengetahuan.

05S2- Peningkatan keahlian karyawan, baik

CSF3 dari sisi perbaikan proses perjualan maupun pengetahuan produk dan solusi.

05S3 Strategi bisnis 3:

Pendekatan solusi terintegrasi yang berorientasi pada peningkatan nilai tambah dan kepuasan pelanggan pada seluruh segmen bisnis.

05S3- Pengembangan portofolio bisnis layanan CSF1 yang menggunakan metodologi VSS.

TABEL II

PEMETAAN DARI CSF KE BUSINESS GOALS, DAN BUSINESS GOALS KE IT GOALS UNTUK STRATEGI BISNIS TAHUN 2005

\begin{tabular}{|c|c|c|}
\hline CSF & Business Goal & IT Goals No. \\
\hline $\begin{array}{l}\text { 05S1- } \\
\text { CSF1 }\end{array}$ & $\begin{array}{l}\text { BG05 - Offer competitive } \\
\text { products and services }\end{array}$ & ITG05, ITG24 \\
\hline $\begin{array}{l}\text { 05S1- } \\
\text { CSF2 }\end{array}$ & $\begin{array}{l}\text { BG12 - Provide compliance } \\
\text { with external laws, } \\
\text { regulations and contracts }\end{array}$ & $\begin{array}{ll}\text { ITG02, } & \text { ITG19, } \\
\text { ITG20, } & \text { ITG21, } \\
\text { ITG22, } & \text { ITG26, } \\
\text { ITG27 } & \end{array}$ \\
\hline $\begin{array}{l}\text { 05S1- } \\
\text { CSF3 }\end{array}$ & $\begin{array}{l}\text { BG09-Obtain reliable and } \\
\text { useful information for } \\
\text { strategic decision making }\end{array}$ & $\begin{array}{l}\text { ITG24, ITG12, } \\
\text { ITG20, ITG26 }\end{array}$ \\
\hline $\begin{array}{l}\text { 05S2- } \\
\text { CSF1 }\end{array}$ & $\begin{array}{l}\text { BG15 - Improve and } \\
\text { maintain operational and } \\
\text { staff productivity }\end{array}$ & $\begin{array}{l}\text { ITG07, ITG08, } \\
\text { ITG11, ITG13 }\end{array}$ \\
\hline $\begin{array}{l}\text { 05S2- } \\
\text { CSF2 }\end{array}$ & $\begin{array}{l}\text { BG15 - Improve and } \\
\text { maintain operational and } \\
\text { staff productivity }\end{array}$ & $\begin{array}{l}\text { ITG07, ITG08, } \\
\text { ITG11, ITG13 }\end{array}$ \\
\hline $\begin{array}{l}\text { 05S2- } \\
\text { CSF3 }\end{array}$ & $\begin{array}{l}\text { BG17 - Acquire } \\
\text { maintain } \\
\text { motivated peopled }\end{array}$ & ITG09 \\
\hline $\begin{array}{l}\text { 05S3- } \\
\text { CSF1 }\end{array}$ & $\begin{array}{l}\text { BG04 - Improve customer } \\
\text { orientation and service }\end{array}$ & ITG03, ITG23 \\
\hline
\end{tabular}

Tabel III menunjukkan kode-kode proses pengelolaan TI menurut COBIT yang mendukung pencapaian IT goals yang telah diidentifikasi untuk tahun 2005. Kode PO untuk proses-proses Perencanaan dan Pengorganisasian (Plan \& Organize, kode AI untuk proses-proses Pengadaan dan Implementasi (Acquire \& Implement), kode DS untuk proses-proses Pelayanan dan Dukungan teknis (Deliver \& Support), dan kode ME untuk proses-proses Pemantauan dan Evaluasi (Monitor \& Evaluate).

TABEL III

Kode Proses-Proses PengelolaAN TI yang ReleVAN DENGAN IT GOALS YANG TELAH DIIDENTIFIKASI UNTUK MENDUKUNG STRATEGI BISNIS TAHUN 2005

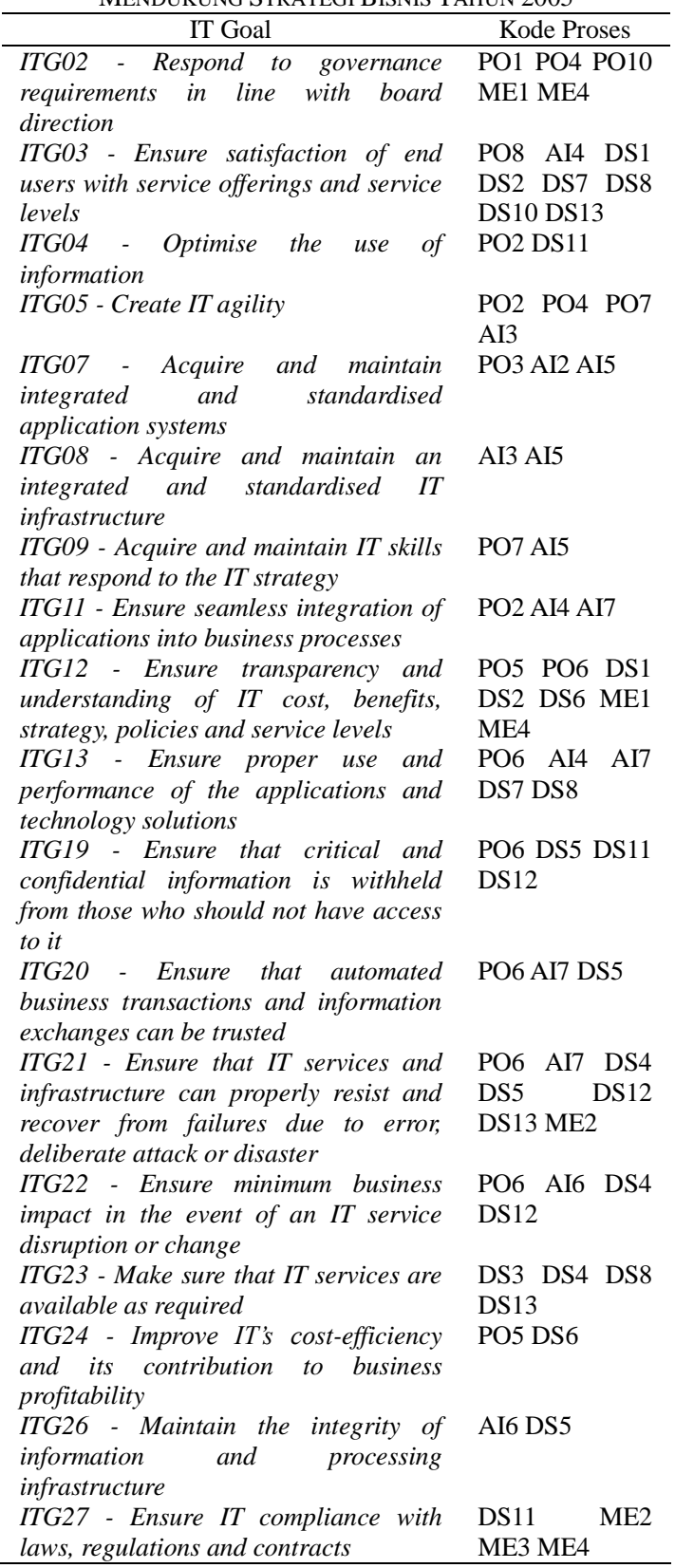


Dari tabel III dapat diketahui proses-proses pengelolaan TI menurut COBIT yang harus diukur tingkat kemapanannya, sebagai indikator kemampuan perusahaan dalam menyelaraskan strategi TI dengan strategi bisnisnya. Analisa yang serupa juga dilakukan untuk periode tahun 2006 dan 2007. Tabel IV menunjukkan proses-proses yang diukur tingkat kemapanannya untuk periode tahun 2005, 2006, dan 2007.

\section{TABEL IV}

Proses-Proses PengelolaAn TI Menurut COBIT yang MenduKung StRategi Bisnis PERIOde TAHUN 2005, 2006 DAN 2007 UNTUK DIUKUR TINGKAT KEMAPANANNYA

\begin{tabular}{|c|c|c|c|}
\hline Proses & 2005 & 2006 & 2007 \\
\hline PO1 Define a strategic IT plan & $\mathrm{V}$ & $\mathrm{V}$ & $\mathrm{V}$ \\
\hline $\begin{array}{l}\text { PO2 Define the information } \\
\text { architecture }\end{array}$ & V & V & V \\
\hline $\begin{array}{l}\text { PO3 Determine technological } \\
\text { direction }\end{array}$ & $\mathrm{V}$ & V & \\
\hline $\begin{array}{l}\text { PO4 Define the IT processes, } \\
\text { organisation and relationships }\end{array}$ & V & V & V \\
\hline PO5 Manage the IT investment & V & V & V \\
\hline $\begin{array}{l}\text { PO6 Communicate management } \\
\text { aims and direction }\end{array}$ & V & V & V \\
\hline PO7 Manage IT human resources & V & V & V \\
\hline $\begin{array}{l}\text { PO8 Manage quality } \\
\text { PO9 Assess and manage IT risks }\end{array}$ & V & V & V \\
\hline PO10 Manage projects & V & $\mathrm{V}$ & V \\
\hline AI1 Identify automated solutions & & V & \\
\hline $\begin{array}{l}\text { AI2 Acquire and maintain } \\
\text { application software }\end{array}$ & V & V & \\
\hline $\begin{array}{l}\text { AI3 Acquire and maintain } \\
\text { technology infrastructure }\end{array}$ & V & V & V \\
\hline AI4 Enable operation and use & $\mathrm{V}$ & V & \\
\hline AI5 Procure IT resources & V & V & \\
\hline AI6 Manage changes & V & V & V \\
\hline $\begin{array}{l}\text { AI7 Install and accredit solutions } \\
\text { and changes }\end{array}$ & V & V & V \\
\hline $\begin{array}{l}\text { DS1 Define and manage service } \\
\text { levels }\end{array}$ & V & V & V \\
\hline DS2 Manage third-party services & V & V & V \\
\hline $\begin{array}{l}\text { DS3 Manage performance and } \\
\text { capacity }\end{array}$ & V & V & \\
\hline DS4 Ensure continuous service & V & V & V \\
\hline DS5 Ensure systems security & $\mathrm{V}$ & V & V \\
\hline DS6 Identify and allocate costs & V & V & V \\
\hline DS7 Educate and train users & V & V & \\
\hline $\begin{array}{l}\text { DS8 Manage service desk and } \\
\text { incidents }\end{array}$ & $\mathrm{V}$ & V & \\
\hline DS9 Manage the configuration & & & \\
\hline DS10 Manage problems & V & V & \\
\hline DS11 Manage data & V & V & V \\
\hline $\begin{array}{l}\text { DS12 Manage the physical } \\
\text { environment }\end{array}$ & V & $\mathrm{V}$ & $\mathrm{V}$ \\
\hline DS13 Manage operations & $\mathrm{V}$ & V & V \\
\hline $\begin{array}{l}\text { ME1 Monitor and evaluate IT } \\
\text { performance }\end{array}$ & V & $\mathrm{V}$ & $\mathrm{V}$ \\
\hline $\begin{array}{l}\text { ME2 Monitor and evaluate } \\
\text { internal control }\end{array}$ & V & $\mathrm{V}$ & V \\
\hline $\begin{array}{l}\text { ME3 Ensure compliance with } \\
\text { external requirements }\end{array}$ & $\mathrm{V}$ & $\mathrm{V}$ & V \\
\hline ME4 Provide IT governance & V & $\mathrm{V}$ & V \\
\hline
\end{tabular}

TABEL V

PemetaAn Proses ITIL Versi 3 Ke Proses Serta Kontrol PROSES COBIT

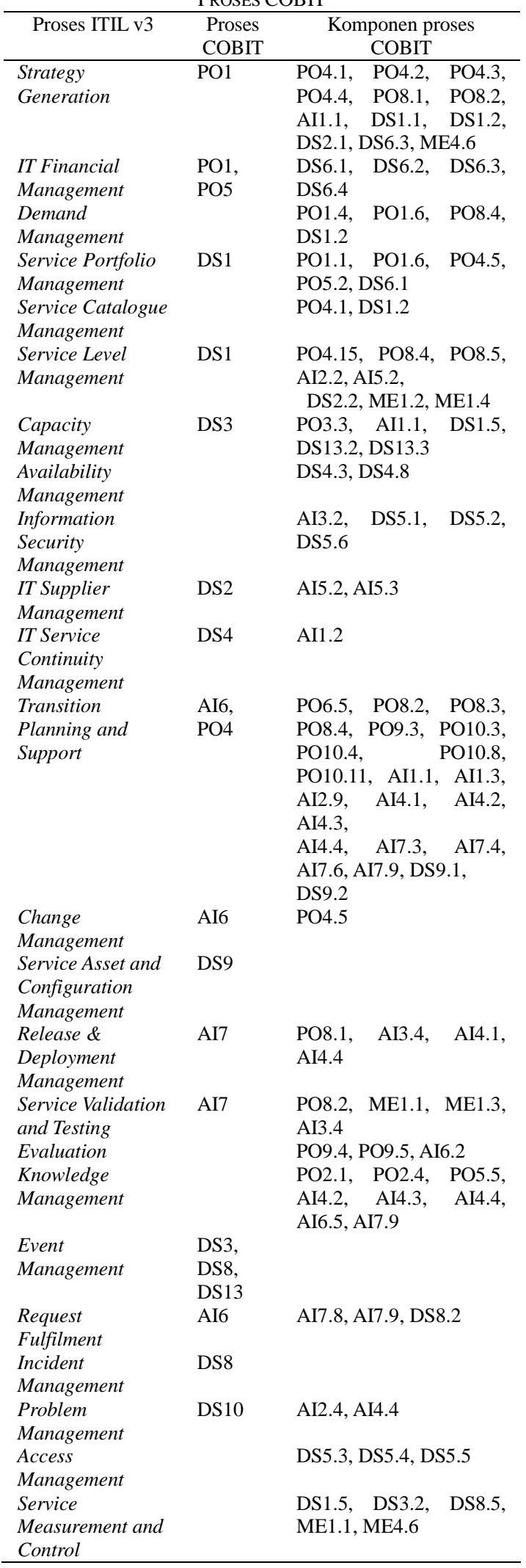

Sebagaimana telah disebutkan pada bagian metodologi, pengukuran tingkat kemapanan 
pengelolaan layanan yang mengukur kemapanan proses-proses pada kerangka kerja ITIL versi 3 dapat digunakan sebagai data untuk mengukur tingkat kemapanan penyelarasan antara strategi TI dan strategi bisnis perusahaan. Tidak semua proses COBIT dapat dipetakan ke proses ITIL. Proses-proses COBIT yang tidak terpetakan tersebut memiliki sebagian komponen (kontrol) proses COBIT yang diterapkan pada prosesproses ITIL.

Dalam penelitian ini, tingkat kemapanan proses-proses ITIL yang menggunakan komponen-komponen suatu proses COBIT dijadikan dirata-ratakan menjadi indikator tingkat kemapanan proses COBIT tersebut. Hal ini dimungkinkan karena tujuan penelitian ini bukan untuk mengukur tingkat kemapanan absolut pengelolaan TI PT ABC, tetapi untuk mengetahui pergerakan tingkat kemapanan dari tahun 2005 hingga tahun 2007 dengan metode pengukuran kemapanan yang konsisten untuk tiap proses yang sama. Tabel V menunjukkan pemetaan antara proses ITIL ke proses serta kontrol proses COBIT menurut IT Governance Institute [7].

Dengan menggunakan data tingkat kemapanan proses-proses ITIL yang dimiliki oleh PT ABC untuk tahun 2005, 2006, dan 2007, diperoleh peta tingkat kemapanan penyelarasan antara strategi TI dan strategi bisnis sebagaimana terlihat pada gambar 1, 2, dan 3, masing-masing untuk periode tahun 2005, 2006, dan 2007.

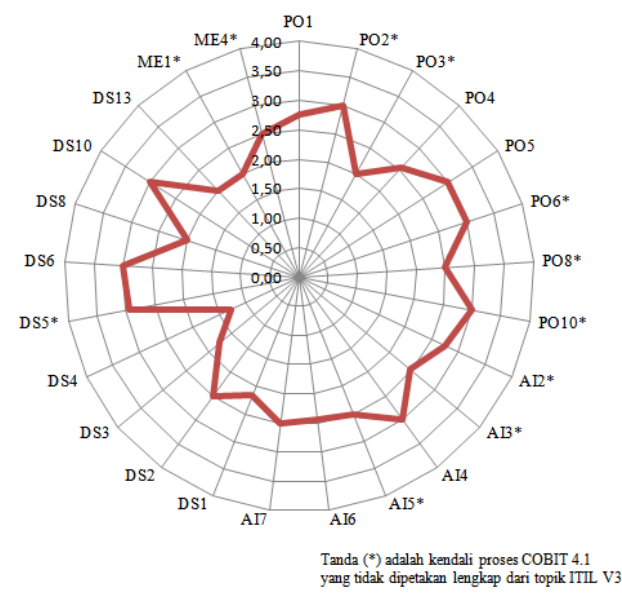

Gambar 1. Tingkat kemapanan penyelarasan antara strategi SI/TI dengan strategi bisnis tahun 2005.

Karena hasil pengukuran tingkat kemapanan ini akan di bandingkan dengan produktivitas perusahaan, maka dihitung nilai rata-ratanya. Sebagaimana terlihat pada gambar 4, ada peningkatan tingkat kemapanan yang berkesinambungan dari tahun 2005 hingga tahun 2007.

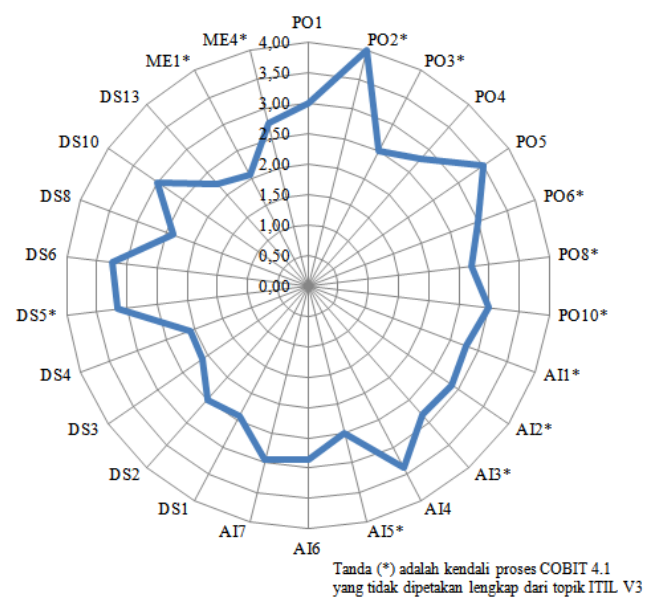

Gambar 2. Tingkat kemapanan penyelarasan antara strategi SI/TI dengan strategi bisnis tahun 2006.

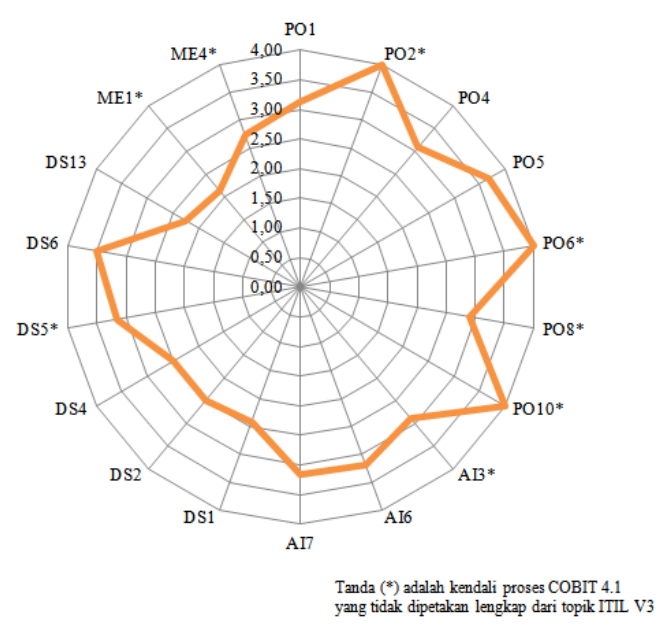

Gambar 3. Tingkat kemapanan penyelarasan antara strategi SI/TI dengan strategi bisnis tahun 2007.

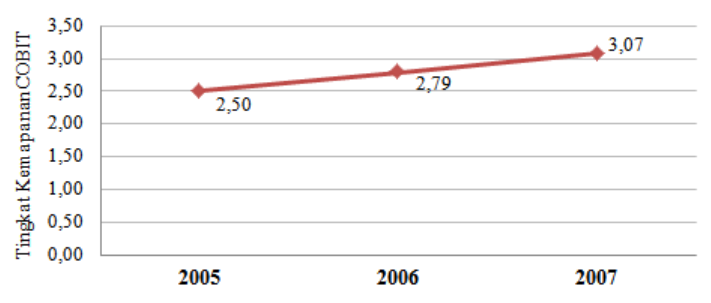

Gambar 4. Peningkatan nilai rata-rata tingkat kemapanan penyelarasan antara strategi SI/TI dengan strategi bisnis PT ABC tahun 2005-2007.

Model pengukuran produktivitas bisnis perusahaan yang digunakan dalam penelitian ini adalah Produktivitas Faktor Total atau Total Factor Productivity. Data komponen produktivitas PT ABC adalah sebagaimana terlihat pada tabel VI. Hasil perhitungan TFP tahunan dari tahun 2005 sampai 2007 ditunjukkan pada gambar 5 . 
TABEL VI

KOMPONEN-KOMPONEN INDIKATOR PRODUKTIVITAS PT ABC

\begin{tabular}{lccc}
\multicolumn{4}{c}{ TAHUN 2005-2007 } \\
\hline $\begin{array}{c}\text { Komponen } \\
\text { indikator } \\
\text { produktivitas }\end{array}$ & $\begin{array}{c}2005 \\
\text { (miliar }\end{array}$ & $\begin{array}{c}2006 \\
(\text { miliar }\end{array}$ & $\begin{array}{c}2007 \\
(\text { miliar }\end{array}$ \\
\hline Pendapatan & 545.46 & 619.04 & 725.58 \\
Laba usaha & 56.32 & 76.73 & 95.05 \\
Jumlah aktiva & 518.80 & 584.84 & 624.56 \\
(IFO) & & & \\
Jumlah karyawan & 958 & 974 & 971 \\
(MP) & & & \\
$\Delta \mathrm{RE}$ & $18.75 \%$ & $11.63 \%$ & $17.57 \%$ \\
$\Delta \mathrm{AE}$ & $-6.58 \%$ & $10.88 \%$ & $7.12 \%$ \\
$\mathrm{~K}($ dari $A P O$ & 0.19 & 0.19 & 0.19 \\
Databook 2010$)$ & & & \\
TFP: & $20.00 \%$ & $9.56 \%$ & $16.22 \%$ \\
$\Delta \mathrm{RE}-(\triangle \mathrm{AE} \times \mathrm{K})$ & & & \\
\hline
\end{tabular}

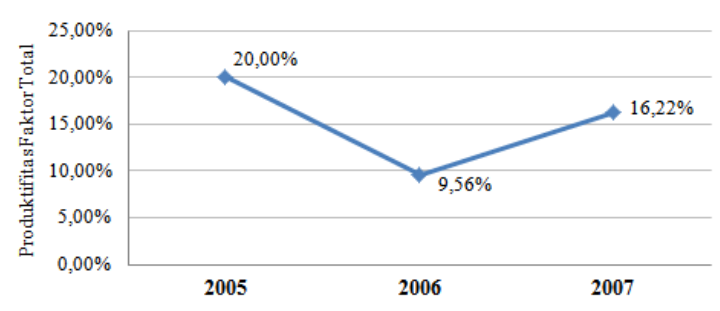

Gambar 5. Nilai Produktivitas Faktor Total (TFP) PT ABC tahun 2005-2007.

Untuk mengetahui pengaruh tingkat kemapanan penyelarasan antara strategi SI/TI dengan strategi bisnis terhadap produktivitas bisnis PT ABC, digunakan pengukuran koefisien korelasi peringkat Spearman. Tabel VII menunjukkan data yang digunakan dalam uji korelasi ini.

TABEL VII

KOMPONEN-KOMPONEN INDIKATOR PRODUKTIVITAS PT ABC TAHUN 2005-2007

\begin{tabular}{ccccccc}
\multicolumn{7}{c}{ TAHUN 2005-2007 } \\
\hline Tahun & $\begin{array}{c}\text { Tingkat } \\
\text { kemapa } \\
\text { nan }\end{array}$ & $\begin{array}{c}\text { Indikat } \\
\text { or } \\
\text { produk } \\
\text { tivitas }\end{array}$ & $\begin{array}{c}\text { Perin } \\
\text { gkat } \\
\text { kema } \\
\text { pana } \\
\mathrm{n}\end{array}$ & $\begin{array}{c}\text { Perin } \\
\text { gkat } \\
\text { prod } \\
\text { uktiv } \\
\text { itas }\end{array}$ & $\mathrm{d}_{\mathrm{i}}$ & $\mathrm{d}_{\mathrm{i}}{ }^{2}$ \\
\hline 2005 & 2.504 & 0.200 & 1 & 3 & 2 & 4 \\
2006 & 2.793 & 0.096 & 2 & 1 & 1 & 1 \\
2007 & 3.068 & 0.162 & 3 & 2 & 1 & 1 \\
\hline
\end{tabular}

Koefisien korelasi peringkat Spearman, $\rho$, yang didapatkan adalah -0.5 , yang berarti tidak ada korelasi positif antara tingkat kemapanan penyelarasan strategi SI/TI dengan strategi bisnis dan tingkat produktivitas perusahaan. Ini berarti bahwa hipotesa $\mathrm{H} 0$ dalam penelitian ini diterima.

\section{Kesimpulan}

Dari pemaparan dan analisis yang telah dilakukan, meskipun tidak dapat dilakukan generalisasi, namun setidaknya kondisi ini berlaku pada organisasi yang menjadi objek dalam penelitian ini, maka didapatkan kesimpulan bahwa tingkat kemapanan penyelarasan strategi SI/TI terhadap strategi bisnis berpengaruh negatif pada nilai Produktivitas Faktor Total perusahaan. Kondisi ini mungkin disebabkan karena adanya perubahan jumlah aktiva (total asset) yang cukup signifikan di perusahaan walaupun jumlah pendapatan (revenue) perusahaan terus meningkat setiap tahunnya. Meskipun demikian, penelitian ini setidak-tidaknya menunjukkan bahwa dampak dari peningkatan tingkat kemapanan tata kelola TI secara umum tidak dapat langsung dirasakan, sehingga tidak dapat diukur dan langsung dibandingkan dengan produktivitas bisnis perusahaan dalam periode tahunan. Selain itu, sudah barang tentu faktor yang mempengaruhi produktivitas suatu organisasi tidak hanya kemapanan tata kelola TI-nya saja. Di sini diperlukan suatu metode untuk menarik batas lingkup kegiatan organisasi yang dukungan SI/TInya cukup intensif.

Penelitian lanjutan yang mungkin dilakukan adalah melihat adanya korelasi ini dengan jeda waktu (time lag) tertentu. Dari hasil pengukuran untuk PT ABC, terlihat adanya indikasi korelasi positif antara tingkat kemapanan tata kelola TI pada suatu periode tahun dengan tingkat produktivitas bisnis pada tahun berikutnya. Sayangnya, data komponen produktivitas perusahaan untuk tahun 2008 tidak dapat dipergunakan karena pada tahun itu terjadi penurunan drastis di luar kewajaran akibat krisis finansial yang melanda dunia. Lamanya jeda waktu diperkirakan juga akan tergantung dari waktu yang dibutuhkan perusahaan untuk merealisasikan solusi-solusi TI yang memberikan nilai tambah bagi bisnis. Kecepatan realisasi ini pun juga ditentukan oleh kesiapan infrastruktur organisasi, baik sumber daya manusia maupun teknologi yang menjadi fondasi bagi pengembangan layanan-layanan bisnis berbasis TI.

\section{Referensi}

[1] J.C. Henderson \& H. Venkatraman, "Strategic alignment: Leveraging information technology for transforming organizations," IBM System Journal, vol. 38, pp. 472-484, 1999 (reprint).

[2] IT Governance Institute, COBIT 4.1 Framework, Control Objectives, Management Guidelines, Maturity Models, Rolling Meadows, USA. 2007.

[3] PT ABC, Broadening Our Moves - 2007 Annual Report, PT ABC, Jakarta, Indonesia, 2008. 
[4] E.M. Nash, "IT and Business Alignment: The Effect on Productivity and Profitability," IT Professional IEEE Computer Society, vol.11, pp. 31-36, 2009.

[5] J. Luftman, “Assessing Business-IT Alignment Maturity," Communications of AIS, vol. 4, article 14, 2000.

[6] H. Christianto, R. Satria, \& Y.G. Sucahyo, "Pengaruh Implementasi Sistem Informasi/Teknologi Informasi terhadap Kinerja Operasional Perusahaan: Studi Kasus pada Perusahaan Jasa Pengiriman," Jurnal Sistem Informasi MTI UI, vol. 3, 2007.

[7] IT Governance Institute, "Aligning COBIT 4.1, ITIL V3 and ISO/IEC 27002 for Business Benefit," A Management Briefing from ITGI and OGC, Rolling Meadows, USA, 2008.
[8] Asian Productivity Organization, $A P O$ Productivity Databook 2010, Keio University Press Inc., Tokyo, 2010.

[9] R.K. Yin, Case Study Research: Design and Methods, 3rd ed., Sage Publication, London, 2002.

[10] S. Siegel \& J.N. Castellan, Nonparametric Statistics for The Behavioral Sciences, 2nd ed., McGraw-Hill Humanities, New York, 1988. 